\title{
Physico-chemical Behavior of the Wastewater Treatment System from Puerto Berrío, Colombia
}

\author{
Luis Eduardo Álvarez Martínez \\ (Faculty of Accounting, Economic and \\ Administrative Sciences, Universidad de \\ Manizales, Colombia) \\ ORCID: 0000-0003-3765-2814
}

\author{
Guillermo Ossa Cifuentes \\ (Faculty of Accounting, Economic and \\ Administrative Sciences, Universidad de \\ Manizales, Colombia) \\ ORCID: 0000-0001-6582-6848
}

\author{
Jhon Jairo Feria Díaz ${ }^{3 *}$ \\ (Department of Civil Engineering, \\ Universidad de Sucre, Colombia) \\ ORCID: 0000-0003-1397-1546
}

\begin{abstract}
Waste stabilization ponds are an excellent alternative for municipal wastewater treatment in many developing countries located in tropical areas. This research study shows behavior results of several physicochemical parameters from the treatment system of Puerto Berrío Municipality in Colombia, a city with a hot and humid weather. Two field monitorings were carried out, one in the dry season and another in the rainy one at the inlet and outlet of the treatment system. Results showed a good behavior in the removal of main pollutants from the treated wastewater.
\end{abstract}

Keywords: Waste stabilization ponds, Physical-chemical parameters, Removal efficiency.

\section{INTRODUCCIÓN}

Pond stabilization systems to treat domestic wastewater is used in many cities in Colombia. Nonetheless, these systems have disadvantages such as unpleasant odor generation and the requirement of vast land areas for their construction. Among the most common types of waste stabilization ponds are the facultative and anaerobic ones, where raw wastewater is exclusively treated by natural processes involving both algae and bacteria [1].

Facultative ponds are those that possess an aerobic, a facultative and an anaerobic zone, being respectively located on the surface, the intermediate and the bottom of the water body. The purpose of these ponds is to stabilize organic matter in an oxygenated medium, mainly provided by present algae [2]. Main biological components in an facultative ponds are bacteria and algae; their interaction constitutes the most important ecological effect on the self-purification process [3]. Bacteria and algae act symbioticly, with the overall result of organic matter degradation. In this process, soluble nutrients (nitrates, phosphates) and carbon dioxide are released in large quantities, which are then used for growth by algae. This way, activity of both is mutually beneficial [2].

In anaerobic ponds, treatment is carried out by action of anaerobic bacteria. As a result of high organic load and short retention period of residual water, the dissolved oxygen content remains very low or zero throughout the year. Thus, most of the suspended solids become incorporated into the layer of accumulated sludge at the bottom and part of the organic load is eliminated [3]. In this type of ponds any kind of microorganisms can be found, from strict anaerobes, in the bottom mud, to strict aerobes in the area immediately adjacent to the surface. In addition to bacteria and protozoa, presence of algae is essential in the facultative ponds, which are the main suppliers of dissolved oxygen [2]. Anaerobic ponds are normally used as the first phase in the treatment of urban wastewater with high organic load and high temperature. When used as pretreatment units, percentage of reduction in waste load is more important than the effluent quality, being necessary to give additional treatment before discharging the waste. They are generally arranged in series with facultative and maturation ponds [4]. Depth ranges between 5 and 10 meters $(\mathrm{m})$ and its hydraulic retention time between 20 and 50 days [5]. One of the biggest problems presented by anaerobic ponds is odor generation, a parameter that fundamentally depends on $\mathrm{pH}$ and the oxide-reduction process occuring in there. One of the gases that can be emitted in an anaerobic pond, causing production of undesirable odors, is sulfhydric acid $\left(\mathrm{H}_{2} \mathrm{~S}\right)$. This compound results, mainly, from bacterial reduction of sulfate ion $\left(\mathrm{SO}_{4}{ }^{2^{-}}\right)$present in water [6].

On the other hand, hydraulic and biological behavior of all waste stabilization ponds is affected by different factors, some controllable by man, others not [7]. These self-dependence factors are: temperature, $\mathrm{pH}, \mathrm{BOD}_{5}, \mathrm{COD}$, total suspended solids, dissolved oxygen, applied organic load, wind patterns, actual retention time, dispersion and mixing characteristics, solar energy, sewage characteristics, environmental factors and amount of nutrients for bacterial metabolism [8].

This research study aimed at evaluating the physical-chemical behavior of the wastewater treatment system of Puerto Berrío municipality in Colombia, to determine its efficiency in the removal of pollutants from wastewater.

\section{MATERIALS AND METHODS}

A. Description of the wastewater treatment system of Puerto Berrio Municipality

The domestic wastewater treatment system for oxidation ponds in Puerto Berrío, Antioquia-Colombia, is made up of an anaerobic pond and two facultative ponds operating in parallel. The anaerobic pond has a volume of $12,960 \mathrm{~m}^{3}$, with $120 \mathrm{~m}$ in length, a $36 \mathrm{~m}$ width and a $3.0 \mathrm{~m}$ depth. Facultative ponds have a volume of $131,265.28 \mathrm{~m}^{3}$ each, with a length of $283.20 \mathrm{~m}$ long, a width of $55.20 \mathrm{~m}$ and a depth of $2.0 \mathrm{~m}$. The surface area of the anaerobic pond is $4,320 \mathrm{~m}^{2}$ and $15,632.64 \mathrm{~m}^{2}$ for each facultative pond. 
Figure 1 shows the location of Puerto Berrío municipality in the Antioquia department and a scheme of the studied wastewater treatment system.

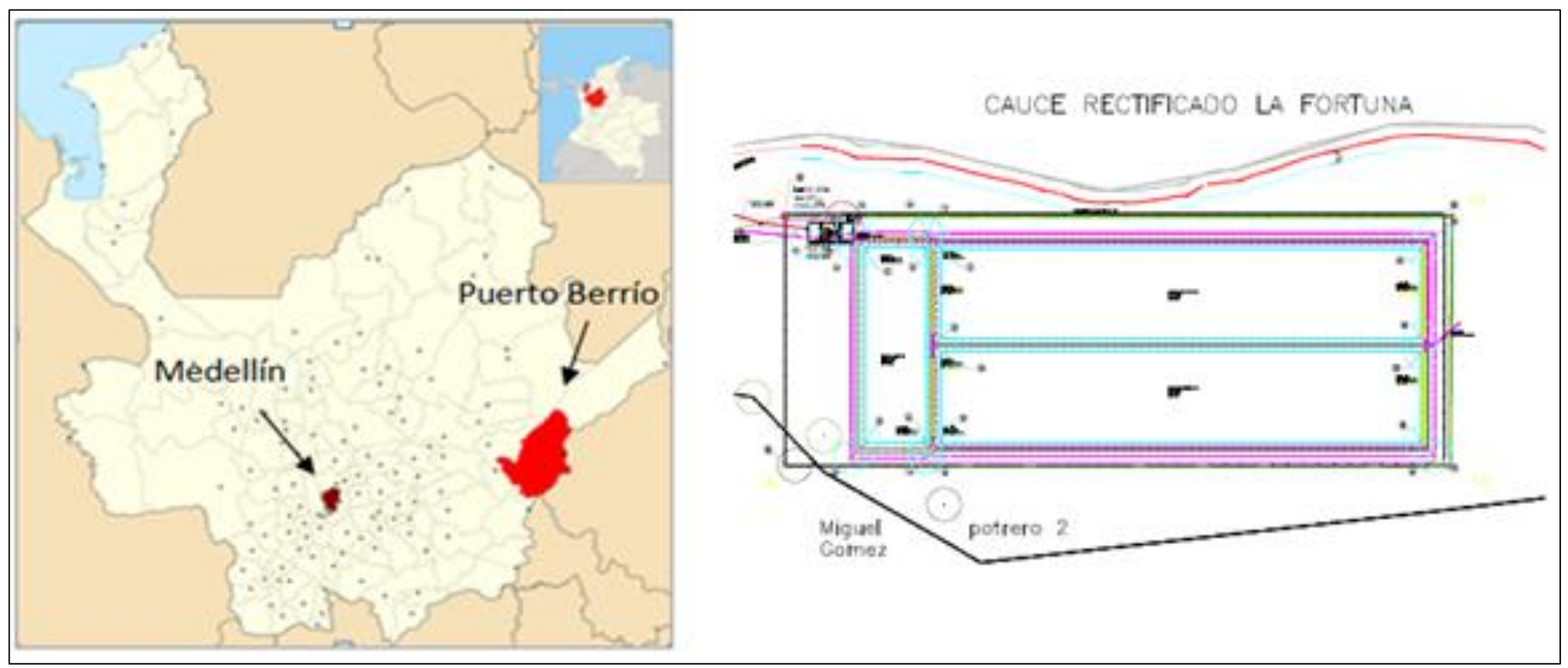

Fig. 1. Location study area

\section{B. Physicochemical parameters and monitoring days}

Two stages were proposed for developing the project: the first one consisted of monitoring the pond on site to measure temperature, $\mathrm{pH}$ and flow. Samples were packaged in containers and refrigerated during 24 hours, taking specific samples every 1 hour, from 6:00 am until 5:00 am, the following day. The second monitoring was done only in the effluent. Subsequently, the respective composition was made and sent to an accredited laboratory to evaluate detergents, total phosphorus, fats and oils, hydrocarbons, nitrates, nitrites, ammoniacal nitrogen, ortho phosphates, dissolved oxygen, $\mathrm{pH}$, sedimentable solids, total suspended solids, $\mathrm{COD}, \mathrm{BOD}_{5}$. The second stage included the processing and analysis of the data obtained in the first phase.

\section{RESULTS AND DISCUSSION}

\section{A. Removal efficiencies of physicochemical parameters}

Figure 2 shows results obtained for $\mathrm{pH}$ at the inlet and outlet of the pond system for the two monitorings performed, while Figure 3 shows results for temperature.
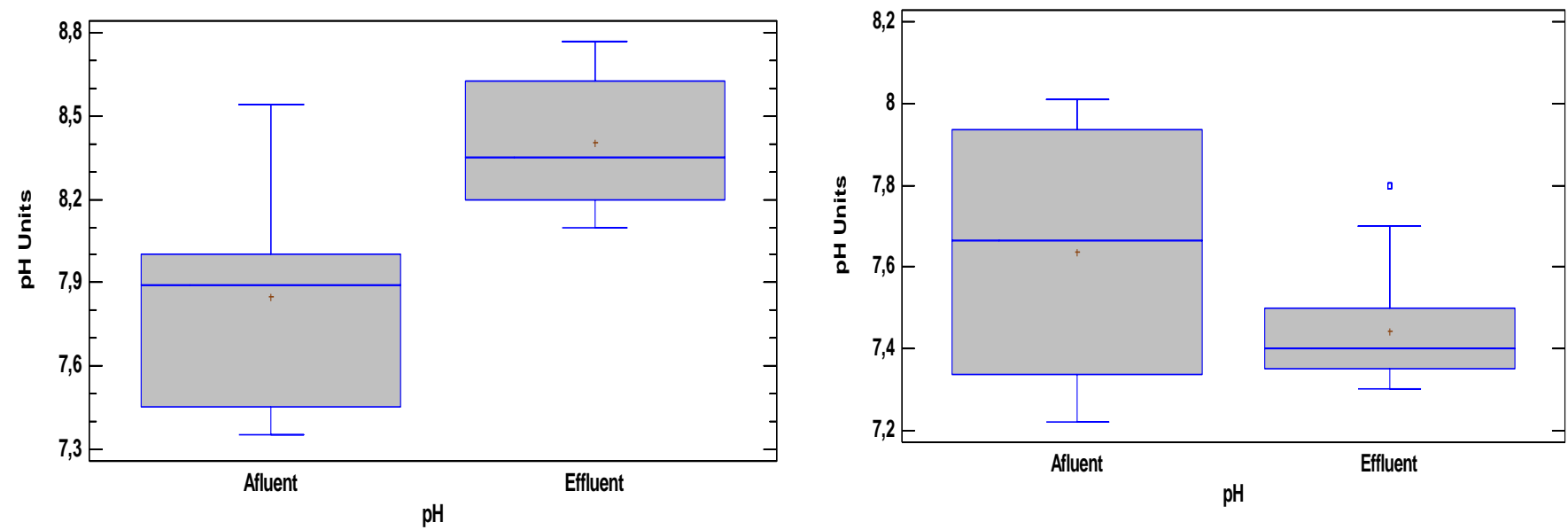

Fig. 2. Behavior of inffluent and effluent $\mathrm{pH}$ from the pond system in: a) first monitoring and b) second monitoring. 

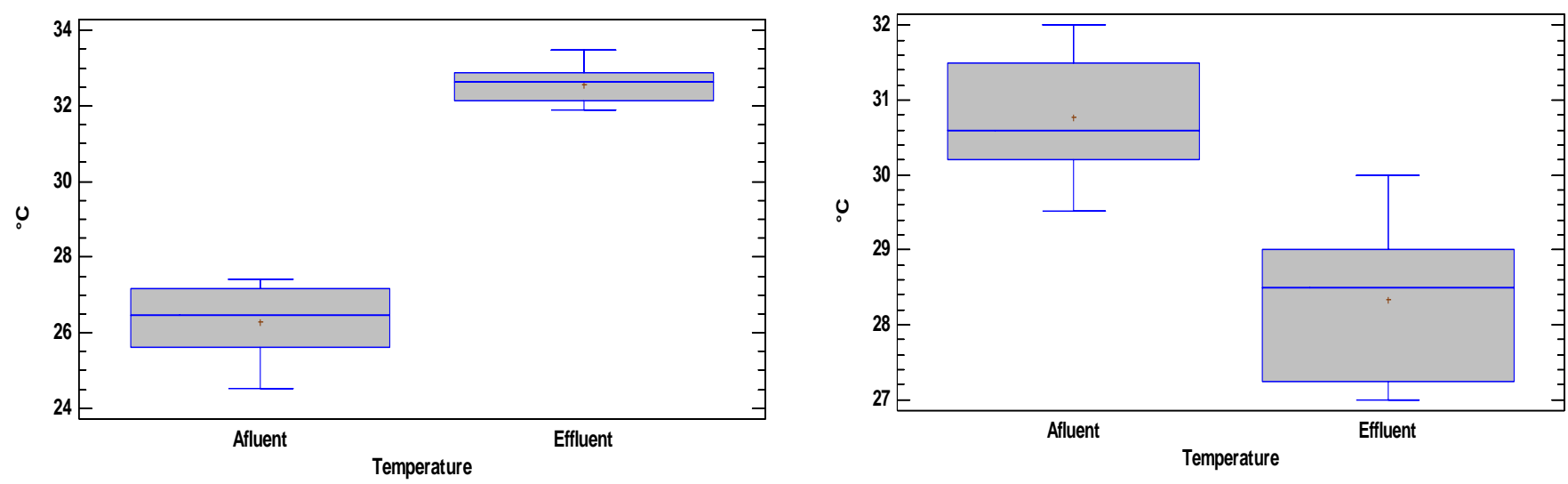

Fig. 3. Behavior of inffluent and effluent temperature from the pond system in: a) first monitoring and b) second monitoring.

To define whether there are significant differences between inlet values and outlet values of both $\mathrm{pH}$ and temperature, a variance analysis was performed. Table 1 shows results of the performed ANOVAS.

Table 1. P-value from the comparison of $\mathrm{pH}$ and temperature obtained in the monitoring.

\begin{tabular}{|l|c|}
\hline Parameters & P-Value \\
\hline Affluent and efluent pH (1st monitoring) & 0.000 \\
\hline Affluent and efluent pH (2nd monitoring) & 0.028 \\
\hline Inlet and outlet temperature (1st monitoring) & 0.000 \\
\hline Inlet and outlet temperature (2nd monitoring) & 0.000 \\
\hline
\end{tabular}

Table 1 shows that $\mathrm{pH}$ and temperature values, at the inlet and outlet, have statistically significant differences, i.e., they change due to the wastewater treatment in the pond. Nonetheless, Figures 1 and 2 indicate that in the first monitoring there is a trend to increase $\mathrm{pH}$ and the temperature, while in the second monitoring the trend is the opposite. This is because the sampling was at different times, one in the dry season and the other one in the rainy season, where intermittent rains occurred, explaining the atypical behavior of these parameters.

Table 2 shows results obtained for the concentrations of pollutants from the wastewater affluent to the treatment system.

Table 2. Results of chemical parameters monitored in the pond system.

\begin{tabular}{|c|c|c|c|c|}
\hline \multirow{2}{*}{ Parameters } & \multicolumn{2}{|c|}{ Monitoring \#1 } & \multicolumn{2}{|c|}{ Monitoring \#2 } \\
\hline & Inlet Lagoons & Outlet Lagoons & Inlet Lagoons & Outlet Lagoons \\
\hline Total Phosphorus (mg P/L) & $5,426 \pm 0,109$ & $2,532 \pm 0,051$ & $6,186 \pm 0,124$ & $3,556 \pm 0,071$ \\
\hline Orthophosphates (mg PO4 3/L & $5,234 \pm 0,262$ & $3,909 \pm 0,195$ & $6,949 \pm 0,347$ & $4,942 \pm 0,247$ \\
\hline Ammoniacal Nitrogen (mg NH3-N/L) & $16,31 \pm 1,79$ & $12,04 \pm 1,32$ & $17,78 \pm 1,96$ & $8,51 \pm 0,94$ \\
\hline Total Nitrogen (mg N/L) & $32,732 \pm \mathrm{ND}$ & $18,620 \pm \mathrm{ND}$ & $28,126 \pm \mathrm{ND}$ & $13,916 \pm \mathrm{ND}$ \\
\hline Nitrates (mg NO3/L) & $<1,000 \pm \mathrm{ND}$ & $<1,000 \pm \mathrm{ND}$ & $<1,000 \pm \mathrm{ND}$ & $<1,000 \pm \mathrm{ND}$ \\
\hline Nitrites $\left(\mathrm{mg} \mathrm{NO} \mathrm{N}_{2} / \mathrm{L}\right.$ & $<0,050 \pm N D$ & $<0,050 \pm N D$ & $<0,050 \pm N D$ & $<0,050 \pm \mathrm{ND}$ \\
\hline $\mathrm{pH}$ (pH units) & $6,95 \pm 0,21$ & $7,39 \pm 0,22$ & $6,89 \pm 0,21$ & $7,44 \pm 0,22$ \\
\hline Fats and oils (mg/L) & $299 \pm 24$ & $<8,0 \pm N D$ & $1805 \pm 144$ & $12 \pm 1$ \\
\hline Hydrocarbons (mg/L) & $54 \pm 4$ & $<9,0 \pm \mathrm{ND}$ & $668 \pm \mathrm{ND}$ & $<9,0 \pm \mathrm{ND}$ \\
\hline Detergents (mg SAAM/L) & $3,675 \pm N D$ & $1,229 \pm \mathrm{ND}$ & - & - \\
\hline Sedimentable Solids (mL/L) & $10 \pm 2$ & $<0,1 \pm \mathrm{ND}$ & $15 \pm 1$ & $<0,1 \pm \mathrm{ND}$ \\
\hline Total Suspended Solids (mg TSS/L) & $725 \pm 28$ & $50 \pm 2$ & $6787 \pm 265$ & $38 \pm 2$ \\
\hline $\mathrm{BOD}_{5}(\mathrm{mg} / \mathrm{L})$ & 114 & 9,17 & 388 & 18 \\
\hline $\mathrm{COD}\left(\mathrm{mg} \mathrm{O}_{2} \quad / \mathrm{L}\right)$ & 741 & 418 & 672 & 1 \\
\hline Dissolved oxygen $\left(\mathrm{mg} \mathrm{O}_{2} / \mathrm{L}\right)$ & $0,13 \pm \mathrm{ND}$ & $5,15 \pm \mathrm{ND}$ & - & - \\
\hline
\end{tabular}

Mean concentration \pm Standard deviation 
The average value found in both samples for the Chemical Oxygen Demand (COD) in the treatment system was 691.5 $\mathrm{mg} / \mathrm{L}$, typical value of domestic wastewater, which should be in a range of 250 to $1,000 \mathrm{mg} / \mathrm{L}$ [9]. For the Biochemical Oxygen Demand $\left(\mathrm{BOD}_{5}\right)$, the average value obtained was 251 $\mathrm{mg} / \mathrm{L}$, being within the typical range for domestic wastewater (110 to $400 \mathrm{mg} / \mathrm{L}$ ). Both parameters are in the strong concentration range for wastewater [9].

For the facultative ponds of the treatment system from Puerto Berrio municipality, the $\mathrm{pH}$ found is in the appropriate range (6.0 to 9.0) to minimize the production of $\mathrm{H}_{2} \mathrm{~S}$, given that the stability of the physicochemical variables, product of the occurrence of higher mixing rates in the water column at night, can generate high emission of $\mathrm{H}_{2} \mathrm{~S}$ gas into the atmosphere and cause bad odors [10].

Regarding nutrients, concentrations found for total phosphorus and total nitrogen are not within the typical ranges for this type of wáter, 4 to $15 \mathrm{mg} / \mathrm{L}$ for phosphorus and 20 to $85 \mathrm{mg} / \mathrm{L}$ for nitrogen, a fact that can generate algae growth problems and present premature eutrophication in the water mirror [2].

Non-homogeneous behavior in the water mirror of the concentrations of the analyzed parameters could be due to the very complex hydrodynamics of the stabilization ponds [11]. Factors such as wind, solar radiation, relative humidity, temperature and geometry of the pond play a very important role in the flow pattern of these treatment systems [12].

Figure 4 shows removal efficiencies of all the physicochemical parameters monitored in the two samples.

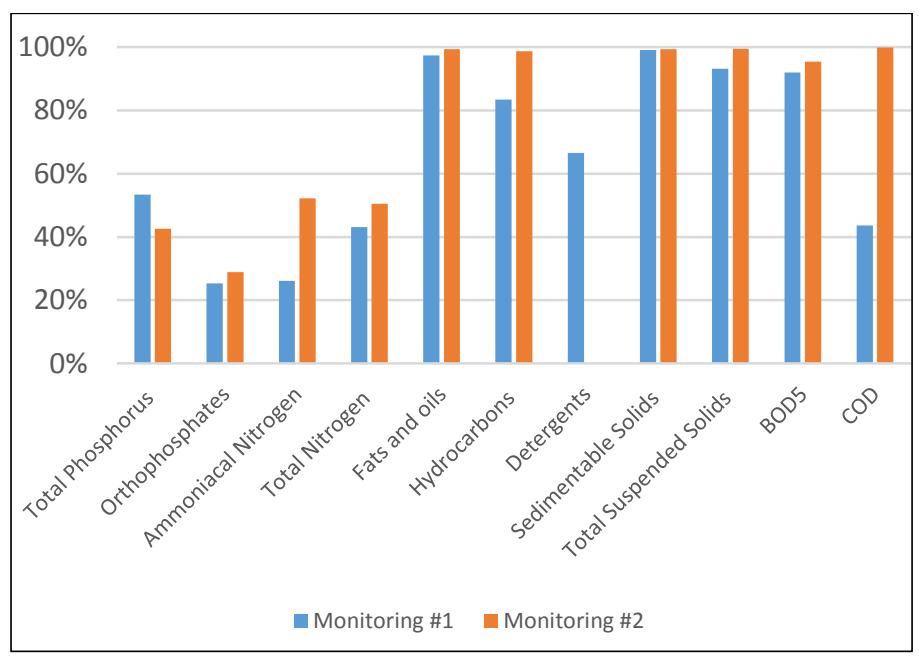

Fig. 4. Removal efficiencies achieved by the pond system

All the parameters analyzed comply with the country's environmental and sanitary regulations [13], which are below the maximum permissible. There was a removal of biochemical oxygen demand (BOD), chemical oxygen demand (COD), sedimentable and total solids, hydrocarbons, fats and oils above $80 \%$. For ponds with proper operation, it would be expected that the surface water body would be heated uniformly and the stratification would be given as a function of depth [2], nevertheless, variations occurred during the samplings performed.

\section{CONCLUSIONS}

Regarding the results found in this research study, a good control of the physicochemical parameters and the flow entering the waste stabilization ponds were evidenced, which is essential for the proper operation of the treatment system. There is also a good removal of $\mathrm{BOD}_{5}, \mathrm{COD}$ and total suspended solids. The high temperature conditions at the site where the treatment system is located, allows a large calorific storage capacity to be present in the facultative ponds, favoring organic matter removal.

Wastewater treatment plants must be systems well-managed by Public Services providers and/or by Municipal administrations to avoid trauma to the community and the environmental authorities due to low efficiency, odors and other factors, which can lead to fines and penalties by the state.

\section{ACKNOWLEDGMENTS}

The authors thank the Household Public Utilities Service of Aqueduct, Sewer and Cleaning from Puerto Berrio Municipality - Aguas del Puerto S.A E.S.P-. for all the assistance given to this academic project.

\section{REFERENCIAS}

[1] F. Cortés, A. Treviño, and A. Tomasini, Dimensionamiento de lagunas de estabilización (Jiutepec, México: Instituto Mexicano de Tecnología del Agua, 2017).

[2] S. Rolim, Sistemas de Lagunas de Estabilización (Bogotá, Colombia: Editorial Mc Graw Hill, 2000).

[3] J.A. Romero, Lagunas de Estabilización de Aguas Residuales (Bogotá, Colombia: Editorial Escuela Colombiana de ingeniería, 2005).

[4] J.M. Lizarazo, and M.I. Orjuela, Sistemas de Plantas de Tratamiento de aguas residuales en Colombia (Bogotá, Colombia: Universidad Nacional de Colombia, 2013).

[5] T. Matsumoto, and I. Sánchez, Performance of the anaerobic lagoons with dividing baffle and facultative of the of Santa Fe do Sul (São Paulo, Brazil), Revista Ingenierías Universidad de Medellín, 15(29), 2016, 27 42. DOI: $10.22395 /$ rium.v15n29a2.

[6] Metcalf y Eddy INC., Ingeniería Sanitaria, Redes de Alcantarillado y Bombeo de Aguas Residuales (Barcelona: Editorial Labor. S.A., 1985).

[7] F. Yánez, Avances en el Tratamiento de Aguas Residuales por Lagunas de Estabilización (Lima, Perú: CEPIS, 1982).

[8] M.D. Moreno, Depuración por Lagunaje de Aguas Residuales, Manual de Operadores (Madrid: Ministerio de Obras Públicas y Transportes (MOPT), 1991).

[9] Metcalf y Eddy INC, Wastewater Engineering: Treatmen, Disposal, Reuse, 3th Edition. (Madrid, España: McGrawHill 1995). 
International Journal of Engineering Research and Technology. ISSN 0974-3154, Volume 13, Number 3 (2020), pp. 414-418

(C) International Research Publication House. https://dx.doi.org/10.37624/IJERT/13.3.2020.414-418

[10] G. Correa, H. Cuervo, R. Mejía, and N. Aguirre, Monitoring of the stabilization ponds system in Santa Fé de Antioquia, Colombia, Revista Producción + Limpia, 7 (2), 2012, 36-51.

[11] G. Aldana, and N. Bracho, Simulation and prediction of hydrodynamic performance at university of Zulia's wastewater stabilization ponds using a 3D-Computational Fluid Dynamic (CFD) model, Revista Técnica de la Facultad de Ingeniería, 28(1), 2005, 86-94.

[12] F. Badrot, V. Guinot, and F. Brissaud, Fluid flow pattern and water residence time in waste stabilisation ponds, Water Science \& Technology-WST, 59(6), 2009, 10611068.

[13] Parámetros y los valores límites máximos permisibles en los vertimientos puntuales a cuerpos de aguas superficiales y a los sistemas de alcantarillado público, Resolución número 0631, 17 de marzo de 2015. 